\begin{tabular}{|l|l|l||}
\hline \multicolumn{2}{|c|}{ PublisherInfo } \\
\hline \hline PublisherName & $:$ & BioMed Central \\
\hline \hline PublisherLocation & $:$ & London \\
\hline \hline PublisherImprintName & $:$ & BioMed Central \\
\hline \hline
\end{tabular}

\title{
Evolution and aging flies
}

\begin{tabular}{|l|l|l||}
\hline \multicolumn{2}{|c|}{ ArticleInfo } \\
\hline \hline ArticleID & $:$ & 3796 \\
\hline \hline ArticleDOI & $:$ & $10.1186 /$ gb-spotlight-20001013-02 \\
\hline \hline ArticleCitationID & $:$ & spotlight-20001013-02 \\
\hline \hline ArticleSequenceNumber & $:$ & 233 \\
\hline \hline ArticleCategory & $:$ & Research news \\
\hline \hline ArticleFirstPage & $:$ & 1 \\
\hline \hline ArticleLastPage & $:$ & 2 \\
\hline \hline & & RegistrationDate : 2000-10-13 \\
ArticleHistory & $:$ & OnlineDate \\
\hline \hline ArticleCopyright & $:$ & BioMed Central Ltd2000-10-13 \\
\hline \hline ArticleGrants & $:$ & \\
\hline \hline ArticleContext & $:$ & 130591111 \\
\hline \hline
\end{tabular}




\section{Jonathan B Weitzman}

Email: jonathanweitzman@hotmail.com

The fruitfly methuselah $(m t h)$ gene encodes a G-protein-coupled receptor that has been implicated in signal transduction cascades regulating aging and stress response. In the September 26 Proceedings of the National Academy of Science, Schmidt et al. analyzed single nucleotide polymorphisms (SNPs) within the $m$ th locus of different Drosophila species (Proc Natl Acad Sci USA 2000, 97:10861-10865) and found that $m$ th is one of the fastest evolving fly genes. The polymorphisms result in changes of amino acids in the intracellular and extracellular loops of the receptor, which are probably responsible for signal transduction. The authors also compared populations from different geographical areas, which varied in lifespan (surprisingly, flies from Vermont lived 18\% longer than lines from sunny Florida). Frequency of the most common allelic haplotype of $m$ th correlated with the degrees of north latitude. Future analysis of the molecular consequences of these polymorphisms could provide insights into the role of $m$ th in aging.

\section{References}

1. Gene expression in the Drosophila mutant methuselah, [http://benzerserver.caltech.edu/mth.html]

2. Proceedings of the National Academy of Sciences, [http://www.pnas.org]

This PDF file was created after publication. 